\title{
ARQUEOLOGIA SUBAQUÁTICA - UMA CAÇA AO TESOURO? REFLEXÕES DE GEORGE F. BASS
}

O objetivo desta nota é chamar a atenção para a problemática que envolve os sítios arqueológicos submersos em águas brasileiras, e principalmente os formados por restos de naufrágios. Criouse ao longo dos anos uma tradição de se referir a tais sítios como locais de acesso "impossível", verdadeiros ambientes intransponíveis, para pesquisadores arqueólogos. Mas, do que ninguém se deu conta até hoje, é que esta tradição - lenda, na realidade - foi criada pelos próprios caçadores de tesouros, ou seja, as pessoas mais interessadas em afastar os arqueólogos desse campo de pesquisa.

Assim, o "mito" do alto investimento e do alto risco ressaltado pelos aventureiros, necessários - segundo eles - para se explorar essa gama de sítios, ganhou espaço na mídia, na opinião pública e principalmente no campo de ação da arqueologia brasileira, a qual até a realização de nossas pesquisas, ${ }^{1}$ havia se intimidado frente aos discursos convincentes da livre iniciativa, apesar de não aceitar a justificativa de comercialização do patrimônio arqueológico submerso como uma recompensa justa ao investidor.

Preocupados com esta situação, semelhante a momentos que abalaram outros países em outras épocas, resolvemos publicar na íntegra o célebre e clássico "underground" de George F. Bass $^{2}$ - então presidente do Institut of Nautical Archaeology (INA) - que conseguiu metaforizar a problemática existente entre a caça ao tesouro e a arqueologia subaquática. $\mathrm{O}$ texto foi preparado por ocasião de um debate político sobre a legislação do patrimônio cultural subaquático nos Estados Unidos da América e foi publicado pela Revista Sea History, em 1979.

Segue o texto:

(1) Pesquisas arqueológicas sistemáticas realizadas no ambiente aquático do litoral sul paulista.

(2) Arqueólogo norte-americano, que aprendeu a mergulhar nos anos 50 e foi o primeiro a experimentar as técnicas que permitiram a realização da pesquisa arqueológica subaquática com a mesma seriedade que em superfície.

\section{O homem que roubava as estrelas ${ }^{3}$}

Quando olhei para o céu naquela noite, primeiro pensei que uma nuvem havia coberto uma parte da Via Láctea. Mas o ar fresco da noite não tinha nenhuma umidade. Depois de limpar os meus óculos e olhar outra vez, percebi que a estrela Mizar tinha desaparecido e liguei para o observatório da universidade mais próxima.

"Falta uma estrela" eu disse, "A estrela Mizar não está lá!"’

"No momento não temos nenhuma informação" foi a resposta.

A edição seguinte da Tempus, a nossa melhor revista, trazia uma explicação. Com o título Ciência apresentava uma breve informação:

"O astrônomo Claude Blakely, depois de anos de pesquisa e experimentação, conseguiu finalmente desenvolver um método para capturar estrelas. Por um preço que não revelou, vendeu a estrela Mizar a um colecionador anônimo em Genebra. Este, através de um porta-voz de Nova Iorque, assegurou ao público que a estrela será exposta num planetário particular, dentro dos próximos dois anos, e que centenas de cidadãos assim poderão vê-la"

Indignado, comecei a enviar cartas a revistas, editores e políticos. As estrelas, dizia eu, pertencem a toda a gente. Aos astrônomos cabe fazer os mapas das estrelas, medi-las e estudá-las nos mínimos detalhes. Mas, acrescentava eu, os astrônomos devem correr atrás do conhecimento. Não era suposto possuírem as estrelas. E eu não julgava que o Sr. Blakely devesse ser chamado de astrônomo.

"A sua atitude me choca pela arrogância", respondeu-me um dos mais conhecidos colunistas. "Claude Blakely sabe mais de astronomia do que qualquer doutor, ou então não poderia ter capturado aquela estrela. E de qualquer modo, porque é que os astrônomos profissionais hão de ter todas as estre-

(3) Texto traduzido pelo autor desta nota, com autorização de George F. Bass. 
las? Há um número suficiente por aí afora. $\mathrm{O}$ senhor só está com inveja por nunca ter capturado nenhuma"

A minha objeção de que o público, tal como os astrônomos, tinha direito às estrelas e de que as gerações futuras tinham o direito de vê-las no céu, ficou sem resposta.

Algumas pessoas escreveram aos seus congressistas, mas devido ao fato de a grande maioria viver em cidades poluídas, onde nunca podiam ver qualquer estrela, poucas cartas foram enviadas. Um jovem congressista de um dos Estados, onde o céu era excepcionalmente claro acabou por promulgar uma legislação contra a prática de se capturar estrelas.

Nessa ocasião, porém, Blakely já tinha vendido os direitos do seu sistema de capturar estrelas a um certo número de sócios.

"As mãos viscosas da iniciativa governamental estão tentando arrancar os despojos do trabalho árduo do último dos grandes inventores" trovejou o colunista. "Claude Blakely e os seus sócios representam a última fronteira da iniciativa privada"

$\mathrm{Na}$ noite em que reparei que a estrela Sirius já não estava no céu, abri o Boletim dos Amigos das Estrelas Particulares, que tinha chegado no correio daquela tarde; tinha como logotipo uma águia segurando uma estrela nas suas garras, flanqueada por bandeiras americanas ondulantes.

"Caros cidadãos, escrevam aos seus congressistas sobre a conspiração de inspiração comunista que quer retirar os nossos direitos de capturar e de vender as estrelas. Há milhões de estrelas nos céus, como qualquer criança sabe. E nem sequer se podem ver todas porque algumas delas estão longe demais. Não pode haver qualquer razão racional para se querer que todas elas fiquem lá em cima. Especialmente quando há bilhões de dólares para se ganhar por investidores privados. Manifestem-se por seus direitos de americanos, manifestem-se pela livre iniciativa!"

Entretanto, o céu, à noite, começou a ficar esmorecido. Os investidores andavam atrás das estrelas mais brilhantes e cintilantes, e assim as de primeira magnitude começaram a desaparecer numa proporção alarmante.

Os astrônomos juntaram-se e tomaram posições públicas sobre o que estava acontecendo.

"Conhecimentos preciosos sobre a formação do universo estão se perdendo para sempre. Não me dá nenhum prazer saber que a estrela Betelgeuse está no porão de um duque austríaco qualquer" escreveu um. "Está fora do contexto"

Um senador de um Estado com o céu extremamente poluído declarou para um jornal local: "Finalmente a astronomia está dando dinheiro e não simplesmente gastando-o. Agora serão poupados milhões de dólares de bolsas da Fundação Nacional de Ciência, que de outro modo seriam desperdiçados em telescópios maiores ou em mais rádios-telescópios. Alguma vez todos os astrônomos, gastando todo este dinheiro durante séculos, produziram um centavo para o público? Eles falam de conhecimento. Claude Blakely é o primeiro a mostrar bom senso"

Quando a estrela Polaris foi capturada, tive a certeza de que a maré ia virar a favor dos astrônomos amadores e profissionais. Mas, com exceção de alguns navegadores, a maioria das pessoas estava olhando para as telas de seus aparelhos de televisão e não podiam se preocupar com isso.

"Por que é que eles não usaram o satélite?" Perguntou a minha irmã quando leu um artigo sobre um marinheiro que se perdeu por causa das estrelas desaparecidas e acabou encalhando nas rochas. "É para isso que servem todos estes satélites, não é ?"

"Eles irão roubar satélites logo-logo" murmurei eu. Deixei cair todas as fotografias de noites estreladas uma após uma, numa pilha no chão entre meus pés. "Era assim que costumava ser"

Para finalizar, por indicação do próprio Bass, cabe uma reflexão sobre o tema. Pois, se substituirmos nesta história estrelas por naufrágios, teremos a descrição precisa do que está acontecendo hoje no Brasil frente às tentativas de liberação oficial - em trâmite no Senado Federal - da caça ao tesouro em águas brasileiras.

Vale o alerta! Nós arqueólogos que trabalhamos no ambiente aquático, sabemos que nossas pesquisas não extrapolam os orçamentos previstos para quaisquer outras intervenções arqueológicas em superfície, e nem mesmo arriscamos nossas vidas mais que os outros colegas. Trata-se de uma lenda criada pela livre iniciativa, como já dissemos anteriormente, que temos de combater. Somos totalmente contra a 
comercialização de artefatos provenientes de sítios arqueológicos submersos como justificativa de financiamento da ação aventureira de caçadores de tesouro. Pois, consideramos esses sítios como a parte "molhada" e mais preservada do Patrimônio Cultural da Humanidade, e ninguém tem o direito de explorá-los em benefício próprio.

Gilson Rambelli*

Recebido para publicação em 10 de novembro de 1999.

(*) Museu de Arqueologia e Etnologia da Universidade de São Paulo. Doutorando em Arqueologia, Bolsista FAPESP, Membro do ICUCH / ICOMOS (International Committee on Underwater Cultural Heritage); do ICOMOS-BRASIL; da Sociedade de Arqueologia Brasileira (SAB). 